\title{
Aspects of writing and its correlation with students' reading habit of the eleventh grade in
} SMAN 1 Natar

\author{
Galih Aisha Oktiasti Isella ${ }^{1}$, Ari Nurweni ${ }^{2}$, Lilis Sholihah ${ }^{3}$ \\ FKIP Universitas Lampung, Jl. Prof. Dr. SoemantriBojonegoro No. 1, Rajabasa, Bandar \\ Lampung ${ }^{1,2,3}$ \\ ${ }^{1}$ Correspondence:galihaisha61@gmail.com
}

\begin{abstract}
This research was intended to investigate what aspect of writing has the highest correlation with students' reading habit. This research is quantitative using ex-post facto design. The study was conducted on 28 students of the eleventh grade in SMAN 1 Natar. Research instruments included reading habit questionnaire and writing test. This research used scoring rubric for writing test which covered five aspects of writing; content, organization, vocabulary, language use and mechanic. The data were in form of scores taken from questionnaire and writing test. Moreover, the score of each aspect of writing was analyzed by using Pearson Product Moment Correlation analysis in SPSS 20.0 along with the score of reading habit to get the correlation between two variables. The result of analysis showed that the coefficient correlation between content aspect and reading habit was determined to be 0.514 . Thus, it was implied that content aspect has the highest correlation with reading habit among the five aspects of writing.
\end{abstract}

Keywords: Correlation, Reading Habit, Aspects of Writing.

\section{INTRODUCTION}

Writing is one of the most important skills that language learners need to master.Meyers (2005) stated that writing is the process of discovering, arranging, and placing ideas on paper, as well as reshaping and revising it. Writing is defined as a process of finding a solution or solving a problem in finding fascinating ideas, arranging them, and putting them on paper that is appropriate for the writing project. According to O'Malley \&Pierce (1996), writing is an individual act in which the writer transforms ideas into personal style. Indeed, writing is described as an activity that allows one to freely express oneself.Furthermore, writing skill considered as one of the high levels in communication skills, due to the fact thatlearners should be capable enough to write a sentence precisely. Writing is about how writers convey information using appropriate words to express their ideas on a certain topic without missing or reducing the sense.

Among the four language skills, writing is the most difficult skill for second or foreign learners to master (Richards \& Renandya, 2002). Byrne (1988) classified the writing complexities into psychological, linguistic and cognitive problems. Ariyanti \& Fitriana (2017) also discovered that Indonesian EFL students struggle with grammar, diction, and spelling errors.Students frequently have difficulties while attempting to compose a sentence, paragraph, or textin essay writing. 
According to Jacobs et al. (1981), there are five aspects of writing that the students should be aware of. Content is the main idea, which focuses on how clear and comprehensible the idea, argument, or thesis is. Second, organization is concerned with the systematic arrangement of the information in the text. Finally, vocabulary refers to the choice of words that are acceptable for the context. Fourth, language use is concerned with the grammatical structure of a sentence.Last, mechanics deals with punctuation, spelling, and capitalization. As a result, writing ability requires the ability to express ideas, feelings, and thoughts into grammatically acceptable sentences, which are then organized into appropriate paragraphs or essays. Students need to use their prior knowledge of vocabulary and grammar to develop their thoughts in written form with a clear, accurate, and comprehensible manner.Thus, students have to obtain as much information and knowledge as possible. It is been believed that reading has a strong connection with writing skills.Nunan (2003) postulated that reading is the process of collecting information that has to be integrated with readers' knowledge in order to create meaning. The more students read, the larger knowledge he/she would absorb. These knowledges later would be beneficial for the students if they were asked to write a text.

When reading becomes a habit, it becomes even more useful and effective.Reading, for instance, is called a habit because it is performed on a daily basis. Students need to develop reading habit by performing the desired reading activity every day, so it becomes second nature to them. Reading is intended to improve students' knowledge of the functions and purposes of text, as well as to assist them in producing good quality of writing by providing them with knowledge they can use to construct their own writing and understand the reader's expectations (Meyer et al., 2002). Furthermore,reading habit is a necessary thing since students attain new words, ideas, fact, information, knowledge, and experience from reading activity. The more students read, the more informations he/she will get.Reading and writing skills are said to be so intertwined that it has been reported that good writers are good readers. The secret to be a good writer is to read a lot. Becoming a good writer and a good reader go hand in hand (Kessler, 2006).

There are several researchers who had conducted the research about reading habit.Anggeriyanti (2017) discovered that there was correlation between students' reading habit and their writing skill.It was confirmed by the result of Pearson Product moment calculation where the score was $0.470\left(\mathrm{r}_{\text {value }}\right)>$ than $0.297\left(\mathrm{r}_{\text {table }}\right)$. It means that reading habit and writing skill had a positive significant correlation.Other studies by Motlaq \& Egresh (2016), they found outthat Iranian EFL students who are better readers and writers would write more qualified writings. Furthermore, students who enjoy reading will have a bigger knowledge and understanding, which will help them develop their writing skills.

To sum up, reading habit plays an important role in students' academic activities, especially writing. The above explanations, as well as those of previous researchers, have motivated the researcher to investigate which aspect of writing has the highest correlationwith reading habit.Hopefully, the finding of this research will assist students in overcoming their writing difficulties, as the researcher believes that reading habits have a significant impact on each aspect writing.If students engage in reading activities on a regular basis, they will obtain a lot of 
information, new words, knowledge of sentence's structure, and knowledge of text organization that will help them with their writing.

\section{METHODS}

This research is co-relation study which is one of the ex-post facto design. According to Setiyadi (2018) co-relation study is a study in which the researcher selects a single group and collects data all at once without giving any treatment.The subjects in this research were eleventh-grade students from SMA Negeri 1 Natar. The sample was chosen using cluster random sampling. The sample was chosen by lottery by the researcher. Finally, 28 students were chosen as the research's sample.

The researcher gathers the data on students' reading habits by administering a reading habit questionnaire, which was then distributed using Google Form. The students were then given a writing task to assess their writing skills. Furthermore, the students were required to write their own analytical exposition text and submit their work using Google Form.

Inter-rater reliability was used by the researcher to ensure reliability of the writing task. The first rater in this research is the researcher, and the second rater is the school's English teacher.Scoring rubric from Jacobs et al. (1981) was used to score each aspect of writing. Later, the mean score of each aspect of writing was computed in Pearson Product moment correlation analysis along with the score of reading habit to get the value of the coefficient correlation.

\section{RESULTSAND DISCUSSIONS}

\section{Result}

After the researcher collected the scorereading habit questionaire and writing task, the mean of each aspect of writing score between two raters was calculated to get the data. See the table below:

Table 5. The Mean of Each Aspect of Writing

\begin{tabular}{|cc|}
\hline Aspect of Writing & Mean \\
\hline Content & 20.91 \\
\hline Organization & 14.17 \\
\hline Vocabulary & 14.60 \\
\hline Language Use & 13.54 \\
\hline Mechanics & 4.32 \\
\hline Total & 67.54 \\
\hline
\end{tabular}

In order to find out which aspect of writing has the highest correlation with reading habit. The mean score of each aspect of writing was computed in Pearson Product moment correlation analysis along with the score of reading habit to get the value of the coefficient correlation. The result can be seen from tables below: 
Table 6. The Value of Pearson Product Moment Correlation between Reading Habit and Content Aspect

\section{Correlations}

\begin{tabular}{|llrr|}
\hline & & Reading Habit & \multicolumn{1}{c|}{ Content } \\
\hline \multirow{4}{*}{ Reading Habit } & Pearson Correlation & 1 &, $514^{* * *}$ \\
& Sig. (2-tailed) & &, 005 \\
& $\mathrm{~N}$ & 28 & 28 \\
& Pearson Correlation &, $514^{* *}$ & 1 \\
Content & Sig. (2-tailed) &, 005 & \\
& $\mathrm{~N}$ & 28 & 28 \\
\hline
\end{tabular}

**. Correlation is significant at the 0.01 level (2-tailed).

Table 7. The Value of Pearson Product Moment Correlation between Reading Habit and Organization Aspect

\section{Correlations}

\begin{tabular}{|llrr|}
\hline & & Reading Habit & Organization \\
\hline \multirow{5}{*}{ Reading Habit } & Pearson Correlation & 1 &, $489^{* * *}$ \\
& Sig. (2-tailed) & &, 008 \\
& $\mathrm{~N}$ & 28 & 28 \\
& Pearson Correlation &, $489^{* * *}$ & 1 \\
Organization & Sig. (2-tailed) &, 008 & \\
& $\mathrm{~N}$ & 28 & 28 \\
\hline
\end{tabular}

**. Correlation is significant at the 0.01 level (2-tailed).

Table 8. The Value of Pearson Product Moment Correlation between Reading Habit and Vocabulary Aspect

Correlations

\begin{tabular}{|llrr|}
\hline & \multicolumn{1}{c}{ Reading Habit } & \multicolumn{1}{c|}{ Vocabulary } \\
\hline \multirow{3}{*}{ Reading Habit } & \multicolumn{1}{c}{ Pearson Correlation } &, $509^{* *}$ \\
\cline { 2 - 4 } & Sig. (2-tailed) & 28 &, 006 \\
\cline { 2 - 4 } Vocabulary & $\mathrm{N}$ &, $509^{* *}$ & 28 \\
\cline { 2 - 4 } & Pearson Correlation &, 006 & 1 \\
\cline { 2 - 4 } & Sig. (2-tailed) & 28 & 28 \\
\cline { 2 - 4 } & $\mathrm{N}$ & &
\end{tabular}

**. Correlation is significant at the 0.01 level (2-tailed). 
Table 9. The Value of Pearson Product Moment Correlation between Reading Habit and Language Use Aspect

Correlations

\begin{tabular}{|llrr|}
\hline & & Reading Habit & Language Use \\
\hline \multirow{3}{*}{ Reading Habit } & \multicolumn{1}{l}{ Pearson Correlation } & 1 &, $425^{*}$ \\
\cline { 2 - 4 } & Sig. (2-tailed) & 28 &, 024 \\
\cline { 2 - 4 } & $\mathrm{N}$ &, $425^{*}$ & 28 \\
\cline { 2 - 4 } Language Use & Pearson Correlation &, 024 & 1 \\
\cline { 2 - 4 } & Sig. (2-tailed) & 28 & 28 \\
\cline { 2 - 4 } & $\mathrm{N}$ &
\end{tabular}

*. Correlation is significant at the 0.05 level (2-tailed).

Table 10. The Value of Pearson Product Moment Correlation between Reading Habit and Mechanic Aspect

Correlations

\begin{tabular}{|llrr|}
\hline & & Reading Habit & Mechanic \\
\hline \multirow{2}{*}{ Reading Habit } & Pearson Correlation & 1 &, $375^{*}$ \\
& Sig. (2-tailed) & &, 049 \\
& $\mathrm{~N}$ & 28 & 28 \\
& Pearson Correlation &, $375^{*}$ & 1 \\
Mechanic & Sig. (2-tailed) &, 049 & \\
& $\mathrm{~N}$ & 28 & 28 \\
\hline
\end{tabular}

*. Correlation is significant at the 0.05 level (2-tailed).

Table 11. Summary of Coefficient Correlation Value

\begin{tabular}{|cc|}
\hline Aspect of Writing & Value of Coefficient Correlation \\
\hline Content & 0.514 \\
\hline Organization & 0.489 \\
\hline Vocabulary & 0.509 \\
\hline Language Use & 0.425 \\
\hline Mechanic & 0.375 \\
\hline
\end{tabular}

Based on the table above, the value of coefficient correlation showed that content aspect has the highest correlation with reading habit among the five aspects of writing. The coefficient correlation between reading habit and content aspect was 0.514 with the significant level at the 0.01. Furthermore, the researcher found that the coefficient correlation between reading habit and organization aspect was 0.489 with the significant level at the 0.01 . Vocabulary aspect has the second highest correlation with reading habit, and the coefficient correlation was 0.509 with 
the significant level at the 0.01 . The researcher also found that the coefficient correlation between reading habit and language use aspect was 0.425 with the significant level at the 0.05 . The aspect of writing which has the lowest correlation with students' reading habit is mechanic aspect with the coefficient correlation 0.375 .

\section{Discussion}

Based on the data analysis, it could be seen that content was the aspect of writing that has the highest correlation with reading habit as the computation shows that the value of coefficient correlation is 0.514, which makes it the highest among other aspects of writing such as organization, vocabulary, language use and mechanic.

The finding of this research was in line with the statement of Meyer et al. (2002), they stated that reading is intended to improve students' knowledge of the functions and purposes of text, as well as to assist them in producing good quality of writing by providing them with knowledge they can use to construct their own writing content and understand the reader's expectations. Moreover, Geva and Tierney (in Linuwih and Winardi, 2020) had high school students read several compare and contrast texts with the same topic from time to time and then they were asked to write similar kind of text with the same topic as well. The researchers found that the format of the students' writing were influenced by the format of the text read and the informations that they found on students' writing were also from the text read.

Furthermore, Tierney and Leys (in Linuwih and Winardi, 2020) stated reading and writing are connected since certain components of reading acquisition are included in the writing process. The writer's style, the expressed idea, and the additional materials and the acquisition itself are the components. This mean that students had to go through a process of bringing their comprehension from reading, constructing the ideas, and putting it all together in a good piece of writing. Anh (2019) stated that reading is a very useful tool in helping learners improve their writing ability because the reading process helps learners gain access to content written by others.

When students have a good quality of reading habit, they notice the text's content. Through reading, students learn the power of a strong introduction and eventually use such knowledge and information, and later develop these ideas as they write their own pieces. While reading different types of texts frequently, students are encouraged to pay attention to and learn consciously about new informations and ideas, they also have better ability to construct these ideas which is essential in making a good content for their writing.

According to the findings of those previous studies and the finding of this research, it can be concluded reading habit plays an important role in students' writing skill, especially in the content aspect. It means the better quality of students' reading habit, the better their ability to construct a good content for their writing. This happened because there is a process which students bring their understanding from reading material, figuring out the ideas for the content, and compose it into their writing. 


\section{CONCLUSIONS AND SUGGESTIONS \\ Conclusions}

Reading habit was positively correlated with each aspect of writing, and content aspect has the highest correlation with reading habit among the five aspects of writing such as organization, vocabulary, language use and mechanic. The computation in Pearson Product moment correlation analysis showed that the value of coefficient correlation between reading habit and content aspect is 0.514 . Students who have a good quality of reading habit also have a high score in content aspect of their writing works. Students learn the importance of gaining informations and knowledges through reading activity, and they eventually utilize these knowledges and informations to create their own concepts and ideas when they write their own works.

\section{Suggestions}

Based on the result, the researcher provides the following suggestions; first, the researcher advised English teacher to focus more on the students' reading activities. This can be accomplished by assigning students to read in class and at home. Furthermore, when teaching writing, English teacher should give an assignment for the students to read a certain topic that is related to the material as much as possible. Second, English teachers should provide popular English texts or reading materials in learning activity. This will encourage students to enjoy and be excited in reading English.Last, since the researcher used analytical exposition text for the students' writing task in this research, the further research is advised to use a different form of text.

\section{REFERENCES}

Anggeriyanti, W. (2017). The Correlation between Students' Reading Habit and Their Writing Skill. Journal :ICoTE Proceedings on 1 st International Conference on Teaching and Education, 1, 205-214.

Anh, D.N. (2019). EFL Student's Writing Skills: Challenges and Remedies. IOSR Journal of Research \& Method in Education (IOSR-JRME), 9 (6), 74-84.

Ariyanti, A., \& Fitriana, R. (2017). EFL Students' Difficulties and Needs in Essay Writing. Advances in Social Science, Education and Humanities Research (ASSEHR),158, 111121.

Byrne, D. (1988). Teaching Writing Skills. London: Longman Press.

Fareed, M., Ashraf, A., \& Bilal, M. (2016). ESL Learners' Writing Skills: Problems, Factors and Suggestions. Journal of Education and Social Sciences, 4 (1), 81-92.1

Jacobs, H. L., Zingraf, S. A., Wormuth, D. R., Hartfiel, V. F., \& Hughey, J. B. (1981). Testing ESL Composition: A Practical Approach. Rowley, MA: Newbury House.

Kessler, R. E. (2006). Contemporary Issues and Decisions: Reading, Writing, and Thinking in Today's World. New York, NY: Longman Pearson Education. 
Linuwih, E.R., \& Winardi, Y.K. (2020). The Influence of Reading Habit on Students' Writing Skill. Anglo-Saxon : Jurnal Ilmiah Program Studi Pendidikan Bahasa Inggris, 11 (1), 3747.

Meyer, B. J., Middlemiss, W., Theodorou, E., Brezinski, K. L., McDougall, J., \& Bartlett, B. J. (2002). Effects of Structure Strategy Instruction Delivered to Fifth-grade Children Using the Internet With and Without the Aid of Older Adult Tutors. Journal of Educational Psychology, 94, 486-519.

Meyers, A. (2005). Gateways To Academic Writing: Effective Sentences, Paraghraps, and Essays. New York: Longman.

Motlaq H. S., Egresh N. (2016). The Relationship between Reading Ability and Writing Quality among Iranian EFL Academic Writers.International Journal of Humanities and Cultural Studies, 3 (2), 1270-1287.

Nunan, D. (2003). Practical English Language Teaching. Singapore: McGraw Hill.

O’Malley, J. M., \& Pierce L. V. (1996). Authentic Assessment for English Language Learners: Practical Approaches for Teachers. New York: Addison - Wesley Publishing Company.

Richards, J.C., \& Renandya, W. A. (2002). Methodology in Language Teaching: An Anthology of Current Practice. Cambridge: Cambridge University Press.

Setiyadi, Ag. B. (2018). Metode Penelitian untuk Pengajaran Bahasa Asing Edisi 2; Pendekatan Kualitatif dan Kuantitatif. Yogyakarta: Graha Ilmu. 